\title{
Selection of Rhizobium spp. Isolates for Inoculation of Field Pea (Pisum sativum)
}

\author{
Çiğdem Küçük \\ Harran University, Science and Art Faculty, Department of Biology, Şanlurfa, Turkey \\ For correspondence: cdmkucuk@yahoo.com \\ Received 27 August 2020; Accepted 07 January 2021; Published 25 March 2021
}

\begin{abstract}
Rhizobium isolates from wild pea nodules were characterized on the basis of microbiological characteristics. P4, P7, P12, P14, $\mathrm{P} 16, \mathrm{P} 19, \mathrm{P} 20, \mathrm{P} 22, \mathrm{P} 23$ and $\mathrm{P} 24$ isolates grew at the $4.5 \mathrm{pH}, \mathrm{P} 5, \mathrm{P} 6, \mathrm{P} 11, \mathrm{P} 12, \mathrm{P} 13, \mathrm{P} 14, \mathrm{P} 16, \mathrm{P} 17, \mathrm{P} 19, \mathrm{P} 20$ and P21 isolates grew at $4 \% \mathrm{NaCl}$ and $\mathrm{P} 7, \mathrm{P} 8, \mathrm{P} 10, \mathrm{P} 11, \mathrm{P} 12, \mathrm{P} 14, \mathrm{P} 19, \mathrm{P} 20, \mathrm{P} 22, \mathrm{P} 23, \mathrm{P} 24$ and $\mathrm{P} 25$ isolates grew at $40^{\circ} \mathrm{C}$. Resistance to antibiotics $\left(\mu \mathrm{g} \mathrm{mL}^{-1}\right)$ was investigated in a large propotion of isolates; streptomycin sulphate (80), rifampisin (40), erythromycin (30), chloramphenicol (100), Penicillin (40). In this study, local Rhizobium bacterial isolates were isolated from wild pea root nodules and their efficacy was investigated. Isolates significantly increased plant dry matter weight. The highest nitrogen fixation was achieved with P4 inoculation. Glutamine synthetase and leghemoglobin content of the nodules were determined in the inoculated with the highest P4 isolate. (C) 2021 Friends Science Publishers
\end{abstract}

Keywords: Glutamine synthetase; Nitrogen fixation; Pisum sativum; Rhizobium isolate

\section{Introduction}

Symbiotic nitrogen fixation occurs between bacteria and legumes (Bourion et al. 2018). These crops are an excellent source of protein and oils for human and animal consumption (Huang et al. 2017). In many studies, it has been explained that nodulation, yield and nitrogen content of the plant are increased with Rhizobium bacteria (Mishra et al. 2009; Rodriguez et al. 2014). Rhizobium bacterial inoculants as biofertilizers to improve soil nitrogen by biological nitrogen fixation have proven to be economically beneficial in all soils deficient of nitrogen (Riah et al. 2014). Appropriate isolates of Rhizobium bacteria to enhance effective symbiosis between the rhizobial isolates and plant on the use of amount of nitrogen fertilizer for early growth of the crops would help to improve yield (Riah et al. 2014). Approximately $80 \%$ of the nitrogen on land is providedby symbiotic nitrogen fixation (Fujita et al. 2014).

Nitrogen fixing root nodule bacteria are generally isolated from root nodules of legume plants (Peix et al. 2015; Bourion et al. 2018). The use of field pea as a forage legume in Turkey requires the introduction of the corresponding symbionts. This species has wide adaptation and produces high quality forage under grazing regimes (Huang et al. 2017). However, its use is currently limited by some problems. Biofertilizers are environmentally friendly, less expensive and hence lead to sustainable crop production. Field pea, being a legume crop responds to inoculation with Rhizobium inoculation to meet the partial requirement of nitrogen (Mishra et al. 2009). Glutamine synthetase activity has an important role in nitrogen metabolism in legume root nodules (Gordon 1991). Leghaemoglobin, glutamine synthetase and sucrose synthetase contents are independent of plant growth and environmental conditions (Ceccatto et al. 1998; Dawood et al. 2019). However, very few reports are available regarding the effect of Rhizobium inoculation on field pea. In this study, Rhizobium bacteria were isolated from the root nodules of wild cowpea, the characterization and symbiotic effects of these isolates were investigated.

\section{Materials and Methods}

\section{Experimental details and treatments}

Isolation, purification and phenotypic features: Rhizobium isolates specific to pea were isolated from wild plants collected in non-cultivated fields of semi-arid regions of Turkey. The pink colored root nodules were selected, washed with tap water. Root nodules were then incubated in $15 \mathrm{~s}$ of $95 \%$ ethyl alcohol for $4 \mathrm{~min}$ in sodium hypochlorite for 3-5 min and then washed several times with sterile distilled water. The root nodules were crushed with forceps and the bacteria $\mathrm{s}$ olution was inoculated into the Yeast Extract Mannitol (YEM) agar, were incubated at $28^{\circ} \mathrm{C}$ for 3-5 days (Jordan 1984). Selected cultures were purified on 
YEM agar (Jordan 1984), colony.

Morphology, Congo red $\left(25 \mu \mathrm{g} \mathrm{mL}^{-1}\right)$ absorption, acid reaction in YEMA containing bromthymol blue $(25 \mu \mathrm{g}$ $\mathrm{mL}^{-1}$ ) and Gram reactions of the isolates were made and confirmed as Rhizobium bacteria. The isolates were transferred to the YEM broth and glycerol mixture and stored at $-80^{\circ} \mathrm{C}$. Sodium chloride tolerance of bacterial isolates was determined on YEM broth containing 0, 0.5, 1, 2, 3, 4 and 5\% (w/v) $\mathrm{NaCl}$ (Küçük et al. 2006). Tolerance of the isolates to different temperatures $(4,15,20,25,30,37$ and $40^{\circ} \mathrm{C}$ ) was investigated in petri dishes containing Yeast extract mannitol agar (Küçük et al. 2006). The growth at the different $\mathrm{pH}$ values of the isolates was investigated. After incubation, bacterial growth was noted (Küçük et al. 2006). Bacterial isolates were inoculated into streptomycin sulphate (Str, $80 \mu \mathrm{g} \mathrm{mL}^{-1}$ ), rifampisin (Rif, $40 \mu \mathrm{g} \mathrm{mL}^{-1}$ ), erythromycin (Ery, $30 \mu \mathrm{g} \mathrm{mL}^{-1}$ ), chloramphenicol (Chl, 100 $\mu \mathrm{g} \mathrm{mL}^{-1}$ ), Penicillin (Pen, $40 \mu \mathrm{g} \mathrm{mL}^{-1}$ ) containing Yeast extract mannitol agar (Küçük et al. 2006). Carbon (C) sources $(10 \%)$, nitrogen sources $(1 \%)$ and organic acids $(1 \%)$ were added to the sterilized basal salts liquid medium by filtration $(0.45 \mu \mathrm{m})$. The bacterial isolates were added to the medium and incubated for 5 days (Küçük et al. 2006). For the evaluation of carbon sources, the medium was added fructose, glucose, mannitol, sucrose, starch, dulcitol, citrate and rhamnose. For the nitrogen sources the medium was applied with mannitol and the following compounds were added L-asparagine, L-trytophan, thymine and glycine (Küçük et al. 2006).

\section{Pot experiment}

The symbiotic effects of bacterial isolates on peas were evaluated in potted trials containing sterile soil. Some physical and chemical properties of soil used were analyzed according to Kacar and Katkat (2007). The healthy pea seeds were selected. The seeds were incubated in $1 \%$ sodium hypochlorite for $5 \mathrm{~min}$, in $70 \%$ ethanol for $3 \mathrm{~min}$ and the surface sterilization was completed by washing several times with sterile distillated water. The isolates were incubated at $150 \mathrm{rpm}, 28^{\circ} \mathrm{C}$ for 4 days in yeast extract mannitol broth medium. The sterilized seeds were treated with bacterial cultures $\left(10^{9}\right.$ colony forming units $\left.\mathrm{mL}^{-1}\right)$. Three seed was sown per plastic pot (20 cm diameter) and were filled with $500 \mathrm{~g}$ of sterilised soil.

Treatments included the 25 isolate isolated from wild pea, $\mathrm{N}$ application, uninoculated control (no inoculation or nitrogen) and reference isolate Rhizobium leguminosarum. Reference isolate was obtained from USDA. $4 \mathrm{~kg} \mathrm{da}^{-1}$ $\mathrm{NH}_{4} \mathrm{NO}_{3}$ was given as nitrogen application. Triple super phosphate (as $8 \mathrm{~kg} \mathrm{da}^{-1} \mathrm{P}_{2} \mathrm{O}_{5}$ ) has been applied to all applications. Experiment was conducted under greenhouse conditions. The applications were made according to the trial design of randomized plots as three parallel. After flowering of plants, plants were harvested, nodule was determined. The plants were dried at $65^{\circ} \mathrm{C}$ for $24 \mathrm{~h}$, weighted and milled to determine $\mathrm{N}$ by Kjeldahl method (Jordan 1984). The nitrogen content (shoot dry weight x N concentration) in the plant and the fixed nitrogen (plant $\mathrm{N}$ content in inoculated pots) were calculated (Beck et al. 1993). Symbiotic activity (\%SE) calculated with the following formula (Beck et al. 1993).

$\mathrm{SE}(\%)=($ Plant $\mathrm{N}$ content in inoculated pots $/$ Plant $\mathrm{N}$ content in $\mathrm{N}$ applied $) \times 100$

\section{Leghaemoglobin, glutamine synthetase and nodule protein}

Root nodules were homogenized with $25 \mathrm{mM}$ phosphate buffer ( $\mathrm{pH} 7.0)$ and $1 \mathrm{~m} M \mathrm{CaCI}_{2} 2 \mathrm{H}_{2} \mathrm{O}$. The content was centrifuged for $30 \mathrm{~min}$ at $20000 \mathrm{rpm}$ at $4^{\circ} \mathrm{C}$.The samples were then analyzed for leghaemoglobin and glutamine synthetase (Gordon 1991). Reaction mixture for glutamine synthetase $0.2 \mathrm{~mL} 250 \mathrm{mM}$ Tris $\mathrm{HCl}, \mathrm{pH} 7.2 ; 0.2 \mathrm{~mL}$ of 30 $\mathrm{m} M$ ATP, $\mathrm{pH} 7.0 ; 0.2 \mathrm{~mL} 500 \mathrm{mM} \mathrm{MgSO} 4 ; 0.2 \mathrm{~mL}$ of 300 $\mathrm{m} M$ glutamate $(\mathrm{pH} 7.0)$ and $0.25 \mathrm{~mL}$ of supernatant were formed. The content was read in the spectrophotometer at 540 nm (Ceccatto et al. 1998; Dakora et al. 1991). The data were expressed in $\mu$ mole of $\gamma$-glutamyl-hydroxamate $\mathrm{min}^{-1} \mathrm{mg}^{-1}$. To determine the leghemoglobin content, the supernatant was extracted in the Drabkins solution and centrifuged at $20000 \mathrm{rpm}$ for $30 \mathrm{~min}$. Then the supernatant was read on the spectrophotometer at $540 \mathrm{~nm}$ and the results were given as mg leghaemoglobin $\mathrm{mg}_{\text {protein }}{ }^{-1}$ (Ceccatto $e t$ al. 1998; Küçük 2011).

\section{Statistical analysis}

All varieties were analyzed by using JMP11 statistical program. Comparisons were done using student's t-test. Mean comparisons has been made using a least significant difference test $(P<0.05)$.

\section{Results}

Twenty-five isolates from the pea roots were isolated. The isolates showed different colony characteristics. The colony diameters vary between $0.4-3.3 \mathrm{~mm}$, and they were circular, either opaque. All of the isolates were catalase positive. All retrieved isolates were Gram negative, moderately motile. The isolates varied in tolerance of $\mathrm{pH}, \mathrm{NaCl}$ sensitivity and heat tolerance (Table 1). All of the isolates showed growth in media containing $0,0.5,1$, and $1.5 \% \mathrm{NaCl}(\mathrm{w} / \mathrm{v})$. All isolates were tested for their tolerance to antibiotics (Table 2). The soil used in the study has a clay texture. The soil was slightly alkaline ( $\mathrm{pH}$ 7.74) and other soil chemical properties are as follows; soil organic matter content $(1.71 \%)$, available $\mathrm{K}$ $\left(97.2 \mathrm{~kg} \mathrm{da}^{-1}\right)$, total $\mathrm{N}(0.18 \%)$ and EC $\left(2.45 \mathrm{dS} \mathrm{m}^{-1}\right.$ at $\left.25^{\circ} \mathrm{C}\right)$.

The symbiotic efficacy of local twenty-eight isolates was confirmed by plant nodulation testing (Table 3 ). In this study, inoculation with different local isolates showed differences in some plant characteristics such as plant height, dry nodule weight, root weight, root length biomass, total dry matter, total nitrogen and symbiotic yield. In this 
Selection of Local Rhizobium spp. from Field Pea Nodules / Intl J Agric Biol, Vol 25, No 4, 2021

Table 1: Colony size, $\mathrm{pH}$, temperature and $\mathrm{NaCl}$ tolerance of Rhizobium spp. Isolates

\begin{tabular}{|c|c|c|c|c|c|c|c|c|c|}
\hline \multirow[t]{2}{*}{ Isolate } & \multirow[t]{2}{*}{ Colony size $(\mathrm{mm})$} & \multirow[t]{2}{*}{ Growth at $\mathrm{pH}$ range } & \multicolumn{2}{|c|}{ Max. tolerance to } & \multirow[t]{2}{*}{ Isolate } & \multirow[t]{2}{*}{ Colony size (mm) } & \multirow[t]{2}{*}{ Growth at $\mathrm{pH}$ range } & \multicolumn{2}{|c|}{ Max. tolerance to } \\
\hline & & & Heat $\left({ }^{\circ} \mathrm{C}\right)$ & $\mathrm{NaCl}(\%)$ & & & & Heat $\left({ }^{\circ} \mathrm{C}\right)$ & $\mathrm{NaCl}(\%)$ \\
\hline P1 & 3.2 & $5.5-10.0$ & 37 & 3.5 & P14 & 2.1 & $4.5-10.0$ & 40 & 4 \\
\hline P2 & 2.1 & $5.5-10.0$ & 37 & 3.5 & P15 & 0.6 & $5.5-10.0$ & 37 & 3.5 \\
\hline P3 & 2.0 & $5.5-10.0$ & 37 & 2 & P16 & 2.9 & $4.5-10.0$ & 37 & 4 \\
\hline $\mathrm{P} 4$ & 1.9 & $4.5-10.0$ & 37 & 2 & P17 & 2.2 & $5.5-10.0$ & 37 & 4 \\
\hline P5 & 3.1 & $5.5-10.0$ & 37 & 4 & P18 & 2.3 & $5.5-10.0$ & 37 & 1.5 \\
\hline P6 & 1.3 & $5.5-10.0$ & 37 & 4 & P19 & 0.4 & $4.5-10.0$ & 40 & 4 \\
\hline P7 & 2.4 & $4.5-10.0$ & 40 & 2 & $\mathrm{P} 20$ & 1.8 & $4.5-10.0$ & 40 & 4 \\
\hline P8 & 3.1 & $5.5-10.0$ & 40 & 3 & P21 & 2.1 & $5.5-10.0$ & 37 & 4 \\
\hline P9 & 2.8 & $5.5-10.0$ & 37 & 3 & $\mathrm{P} 22$ & 1.3 & $4.5-10.0$ & 40 & 1.5 \\
\hline P10 & 3.1 & $5.5-10.0$ & 40 & 3.5 & $\mathrm{P} 23$ & 0.8 & $4.5-10.0$ & 40 & 2.5 \\
\hline P11 & 1.1 & $5.5-10.0$ & 40 & 4 & P24 & 1.0 & $4.5-10.0$ & 40 & 1.5 \\
\hline P12 & 0.8 & $4.5-10.0$ & 40 & 4 & P25 & 1.3 & $5.5-10.0$ & 40 & 1.5 \\
\hline P13 & 3.3 & $5.5-10.0$ & 37 & 4 & & & & & \\
\hline
\end{tabular}

Table 2: Antibiotic resistance pattern of root nodule isolates

\begin{tabular}{lll}
\hline Resistance pattern & No. of resistance isolate & $\%$ \\
\hline Str, Rif, Ery, Chl, Pen & P6, P12, P14, P20, P1, P18 & 24 \\
Str, Rif, Ery, Chl & P17, P5, P7, P11, P13 & 20 \\
Str, Rif, Ery, Pen & P2, P4, P15, P10 & 16 \\
Str, Rif, Chl, Pen & P19, P21 & 8 \\
Str, Rif, Ery & P3, P7 & 8 \\
Str, Rif & P8 & 4 \\
Rif, Ery, Chl, Pen & P1, P9 & 8 \\
Rif, Chl & P16, P24 & 8 \\
Rif, Pen & P22 & 4 \\
Ery, Pen & P23 & 4 \\
Ery, Chl, Pen & P25 & 4 \\
\hline
\end{tabular}

study, all isolates tested provided $\mathrm{N}$ to the plant as indicated by dry weight and total nitrogen content. All the isolates that used in the study were effective on plant dry matter compared with the control pots. The lowest values were obtained from the control treatment. However, the total dry weight was taken from native isolated isolates $(\mathrm{P} 4, \mathrm{P} 10$, reference isolate and $\mathrm{P} 14$, respectively). The glutamine synthetase and leghaemoglobin contents in the nodule extracts are shown in Fig. 1. The variance analysis of the obtained data showed that the isolates had significantly effects on shoot dry matter, total nitrogen, total symbiotic efficiency, and efficiency rates. In the application of nitrogen and inoculation with local bacteria, glutamine synthetase activity was found to be higher compared to control. Glutamine synthetase and leghaemoglobin level was found to be different among the Rhizobium isolates with inoculated applications (Fig. 1). Symbiotic activities of the isolates were statistically different.

\section{Discussion}

The isolated bacteria were grown in YMA medium and colony morphology was examined. All of the isolates were examined to be mobile, gram negative and rod shaped. Different between isolates were verified using some morphological properties (Küçük et al. 2006) and ten isolates were high produced of mucus. Küçük et al. (2006) explained the importance of produced mucus by bacterial isolates in plant growth and nodulation formation. There is no salt problem in the soil from which the bacteria are isolated, whereas the isolates were tolerated in media containing 3.5 and $4 \%(\mathrm{w} / \mathrm{v}) \mathrm{NaCl}$ (Table 1). The tolerance of local isolates to some stress conditions was investigated. According to the results, increased $\mathrm{NaCl}$ concentration (5\%) adversely affected the growth of bacterial isolates. Similar observations were reported with isolates from different legumes, including field pea (Küçük et al. 2006; Borucki and Sujkowska 2008).

High salt tolerance is very important property for survival under the hot and dry conditions. None of the isolates grew in the medium containing $5 \% \mathrm{NaCl}$. These results are similar to those of Cordovilla et al. (1994). AbiGhanem et al. (2013) and Wielbo et al. (2015) found that there was a difference in the growth of Rhizobium isolates in salt containing environments and they reported that Rhizobium isolates were more tolerant to salt than the host plant. Rhizobium isolates were found to be more resistant to osmotic stress than legume plants (Cordovilla et al. 1994). It was observed in studies that show different responses to salts of different Rhizobium species (Abi-Ghanem et al. 2013). In this study, $42.8 \%$ of the isolates grew at the $4.5 \mathrm{pH}, 39.2 \%$ of the isolates grew at $4 \% \mathrm{NaCl}$ and $42.8 \%$ of the isolates grew at $40^{\circ} \mathrm{C}$. These results are similar previous reports for different Rhizobium bacteria (Singleton et al. 1982). Although the soil temperature in semi-arid areas exceeds $40^{\circ} \mathrm{C}$ at $5 \mathrm{~cm}$ from the surface, the temperature tolerant 
Küçük et al. / Intl J Agric Biol, Vol 25, No 4, 2021

Table 3: Total $\mathrm{N}$, percent $\mathrm{N}$ derived from $\mathrm{N}_{2}$ fixation, shoot dry matter and nodulation score of field pea, inoculated with different isolates of Rhizobium spp.

\begin{tabular}{|c|c|c|c|c|c|}
\hline Isolate & Shoot dry matter (g plant $\left.{ }^{-1}\right)$ & $\mathrm{N} \%$ & Total N & N Fixed & Nodulation score $^{\#}$ \\
\hline P1 & $0.26 \mathrm{~g}-\mathrm{i}$ & $3.19 \mathrm{a}$ & $8.34 \mathrm{e}-\mathrm{k}$ & 4.47hi & 2 \\
\hline P2 & $0.24 \mathrm{~g}-\mathrm{i}$ & $2.23 c-f$ & $5.22 \mathrm{kl}$ & $5.22 \mathrm{~h}$ & 2 \\
\hline P3 & $0.27 \mathrm{f}-1$ & $2.38 \mathrm{c}-\mathrm{f}$ & $6.51 \mathrm{i}-1$ & $6.51 \mathrm{gh}$ & 1 \\
\hline P4 & $0.58 \mathrm{ab}$ & 2.63a-e & $15.26 \mathrm{ab}$ & $15.26 \mathrm{ab}$ & 1 \\
\hline P5 & $0.53 \mathrm{ab}$ & $2.87 \mathrm{a}-\mathrm{c}$ & 15.09ab & $15.09 \mathrm{a}-\mathrm{c}$ & 2 \\
\hline P6 & $0.35 \mathrm{~d}-\mathrm{f}$ & 2.79a-d & $9.72 \mathrm{~d}-\mathrm{h}$ & $9.72 \mathrm{~d}-\mathrm{g}$ & 2 \\
\hline P7 & $0.31 \mathrm{e}-\mathrm{h}$ & $2.33 \mathrm{c}-\mathrm{f}$ & $7.16 \mathrm{~g}-1$ & 7.16f-h & 1 \\
\hline P8 & $0.43 \mathrm{~cd}$ & $2.57 \mathrm{a}-\mathrm{f}$ & $10.92 \mathrm{~d}-\mathrm{g}$ & $10.92 d-f$ & 1 \\
\hline P9 & $0.42 \mathrm{~cd}$ & $2.68 \mathrm{a}-\mathrm{d}$ & $11.28 \mathrm{c}-\mathrm{f}$ & $11.28 \mathrm{c}-\mathrm{e}$ & 1 \\
\hline P10 & $0.57 \mathrm{ab}$ & 2.61a-e & $14.84 a-c$ & $14.84 a-c$ & 3 \\
\hline P11 & $0.33 \mathrm{ef}$ & $1.49 \mathrm{c}-\mathrm{f}$ & $5.06 \mathrm{f}-1$ & $7.58 \mathrm{e}-\mathrm{h}$ & 3 \\
\hline P12 & $0.50 \mathrm{~b}$ & $0.19 c-f$ & $0.94 \mathrm{~m}$ & 0.941 & 2 \\
\hline P13 & $0.29 \mathrm{e}-\mathrm{h}$ & $1.53 \mathrm{c}-\mathrm{f}$ & $5.00 \mathrm{f}-1$ & 7.50e-h & 1 \\
\hline P14 & $0.55 \mathrm{ab}$ & $2.24 c-f$ & 12.36a-d & $12.36 b-d$ & 2 \\
\hline P15 & $0.28 \mathrm{e}-\mathrm{h}$ & $1.98 \mathrm{c}-\mathrm{f}$ & $5.54 \mathrm{1}-1$ & $5.54 \mathrm{gh}$ & 3 \\
\hline P16 & $0.22 \mathrm{~h}_{1}$ & $2.27 \mathrm{c}-\mathrm{f}$ & $5.09 \mathrm{kl}$ & $5.09 \mathrm{~h}$ & 1 \\
\hline P17 & $0.49 \mathrm{bc}$ & $2.47 \mathrm{c}-\mathrm{f}$ & $12.24 a-d$ & $12.25 b-d$ & 2 \\
\hline P18 & $0.43 \mathrm{~cd}$ & $2.6 a-d$ & 11.61a-e & $11.62 \mathrm{~b}-\mathrm{d}$ & 1 \\
\hline P19 & $0.37 \mathrm{de}$ & $2.32 \mathrm{c}-\mathrm{f}$ & $8.65 \mathrm{~d}-1$ & $8.65 \mathrm{~d}-\mathrm{g}$ & 3 \\
\hline P20 & $0.22 \mathrm{~h}$ & $2.11 \mathrm{c}-\mathrm{f}$ & 4.64lm & $4.64 \mathrm{~h} 1$ & 2 \\
\hline P21 & $0.32 \mathrm{e}-\mathrm{g}$ & $1.90 \mathrm{c}-\mathrm{f}$ & 6.161-1 & $6.16 \mathrm{gh}$ & 2 \\
\hline P22 & $0.23 \mathrm{~h}_{1}$ & $2.38 \mathrm{c}-\mathrm{f}$ & $5.351-1$ & $5.35 \mathrm{~h}$ & 1 \\
\hline P23 & $0.43 \mathrm{~cd}$ & 2.71a-d & $11.58 \mathrm{a}-\mathrm{e}$ & $11.58 b-d$ & 3 \\
\hline P24 & 0.191 & $1.18 \mathrm{c}-\mathrm{f}$ & $2.60 \mathrm{~lm}$ & 3.901 & 2 \\
\hline P25 & $0.27 \mathrm{~g}-1$ & $2.53 \mathrm{a}-\mathrm{f}$ & $6.75 \mathrm{~h}-1$ & $6.75 \mathrm{gh}$ & 1 \\
\hline R. leguminosarum & $0.57 \mathrm{ab}$ & $2.86 \mathrm{a}-\mathrm{c}$ & $16.34 \mathrm{a}$ & $16.34 \mathrm{a}$ & 1 \\
\hline${ }^{*} \mathrm{~N}$ & $0.59 \mathrm{a}$ & $3.13 \mathrm{ab}$ & $18.61 \mathrm{a}$ & $18.61 \mathrm{a}$ & 0 \\
\hline Control & 0.181 & $2.11 \mathrm{c}-\mathrm{f}$ & $3.861 \mathrm{~m}$ & & 0 \\
\hline LSD & 0.087 & 0.686 & 3.809 & 3.885 & \\
\hline
\end{tabular}

${ }^{*} \mathrm{~N}$ : $\mathrm{NH}_{4} \mathrm{NO}_{3}{ }^{\#} 1$ : very well nodulated, 2: moderately nodulated, 3: less nodulated on the roots. Different letters indicate means separation within columns.

Rhizobium bacteria have not affected the ability of nodule formation (Wielbo et al. 2015). High temperature resistance between Rhizobium bacteria is important in the selection of local isolates (Wielbo et al. 2015). On the other hand, Meghvansi et al. (2010) reported that the high temperature adversely affected the viability of Rhizobium bacteria. The isolates isolated from arid and warmer regions were more tolerant to temperature and drought. It was thought that the tolerances of the isolates to the drought and temperature could be related to the geographic origin (Mutch and Young 2004; Wielbo et al. 2015). Rhizobium spp., isolated from pea roots grown in West Africa, was reported to grow at $40^{\circ} \mathrm{C}$ (Muniz et al. 2017).

In general, the Turkish isolate were able to use several compounds as sole carbon sources, as reported for other Rhizobium bacteria (Riah et al. 2014). 25\% of the isolates showed multiple resistances to five different antibiotics. The multiple antibiotic resistances was associated with plasmids and this was more common in Gram-negative bacteria (Küçük et al. 2006). This result is consistent with literature showing that Rhizobium bacteria are resistant to high concentration of antibiotics (Küçük et al. 2006). The antibiotic resistance of bacteria in genetic studies is extremely important (Riah et al. 2014). There are three knows determinants of bacterial permeability to an antibiotics; hydrophobicity, electrical charge and size of the antibiotics (Abaidoo et al. 2002). Phenotypic characterization based on intrinsic antibiotic resistance has been used both with a view to isolate identification and taxonomic classification (Riah et al. 2014). There are also no reports of Rhizobium isolates being isolated from field pea nodules in Turkey. Moreover, other studies with native isolates and pea have shown that significantly increased nodulation and symbiotic efficiently (Erman et al. 2009; Mishra et al. 2009). The interaction between bacteria and host plant is particularly important (Muniz et al. 2017). The results of our study revealed that the native isolates had significant effect on the plant total weight according to control (noninoculation and non-fertilizer). Besides, the isolates had significant effects on symbiotic efficiency. On the other hand, the uninoculated controls did not form any nodules. Shoot dry weight was greater with local

Isolate $\mathrm{P} 4$ (580 mg plant $\left.^{-1}\right)$ than in the control treatment, while field pea plants inoculated by reference isolate $R$. leguminosarum gave root dry weight of 560 mg plant ${ }^{-1}$. The shoot dry weight increased by $222.2 \%$ with inoculation of P4 isolate and $216.7 \%$ with inoculation of P10 isolate. It was determined that there were differences between isolates by analysis of variance. Similar results have also been investigated in studies (Mishra et al. 2009; Abi-Ghanem et al. 2013). The symbiotic performances of local isolates were compared with the reference isolates in greenhouse conditions. Inoculation with different isolates resulted in plant $\mathrm{N}$ accumulation of more than $180 \mathrm{mg} \mathrm{N}$ plant.

It was determined that all isolates increased the total 
A

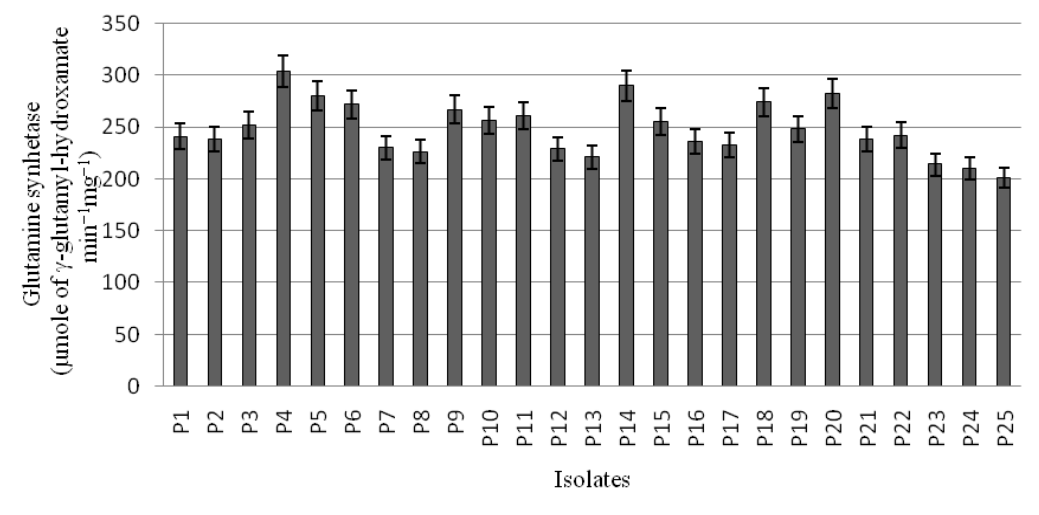

B

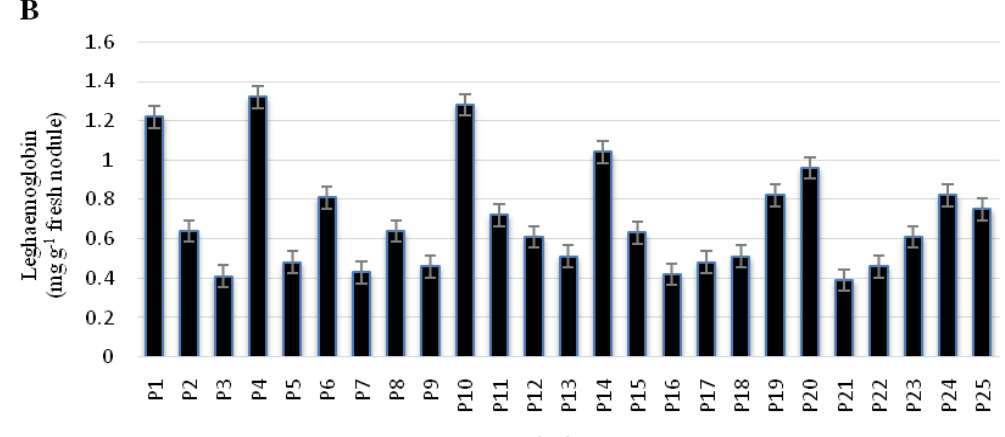

isolate

Fig. 1: Glutamine synthetase and leghaemoglobin determined in nodules of field pea

nitrogen content and dry weight of the plant and provided nitrogen to the plant. Similar evidence of increase in plant growth with Rhizobium inoculation has been reported (Borucki and Sujkowska 2008; Rodriguez et al. 2014). These results could be attributed to the development of efficient symbiosis of field pea with local isolates. These results also show that effective Rhizobium local isolates are more tolerant than standard isolate as observed by Bourion et al. (2018).

The glutamine synthetase activity (304 $\mu$ mol-glutamylhydroxamate $\mathrm{h}^{-1}$ per $\mathrm{g}$ fresh weight) was highest in isolate $\mathrm{P} 4$ inoculation. Similar results were obtained by Ceccatto et al. (1998) for bean plants with inoculation. In a study on root nodules, it was determined that $\mathrm{NH}_{3}$ was assimilated with the help of glutamate synthetase (GS) and NADH-dependent glutamate synthase (NADH-GOGAT) enzymes in amino acids (Gordon 1991). Cordovilla et al. (1994) explained that GS functions as a positive inducer of nitrogenase and those nif genes are controlled by GS. The control of enzyme synthesis was thought to activate the transcription of operons involved in the use of nitrogen source (Cordovilla et al. 1994). Leghaemoglobin levels differed between inoculations. Isolate P4, P10, P1 and P14 with inoculation showed a maximum activity $(1.32,1.28, \quad 1.22$ and $1.04 \mathrm{mg}$ leghaemoglobin mg protein ${ }^{-1}$, respectively).

\section{Conclusion}

In this study, leghaemoglobin, glutamine synthetase and plant growth were associated with bacterial inoculation. This can help to determine the effective isolate in nitrogen fixation similar results have also been reported by various investigators (Cordovilla et al. 1994; Küçük 2011). It was determined that bacterial inoculation in peas affected nodulation, dry matter weight, $\%$ nitrogen content and fixed nitrogen per plant compared to the control plant. The activities of the isolates differed from each other. However, the leghemoglobin and glutamine synthetase activities determined in root nodules of peas inoculated with different isolates were also found to be different. Therefore, the use of mineral nitrogen fertilizers, which are important in soil, water and air pollution, can be reduced by the use of Rhizobium isolates effective in plant cultivation. In conclusion, our Rhizobium isolates have an ability to fix nitrogen. In similar environmental conditions, bacteria isolate to be inoculated with peas may increase the protein content and yield of peas. However, it can be recommended to the farmer. In later studies, the bacteria will be genetically identified and the genes that play a role in the symbiotic interaction will be identified. 


\section{Acknowledgements}

The author acknowledges the financial grant from University of Harran, Şanlıurfa, Turkey

\section{Author Contributions}

The author of this work has been involved in the entire work, which includes research, design, analysis and final presentation of the study.

\section{Conflict of Interest}

I declare no conflict of interest of any kind

\section{Data Availability Declaration}

All data reported in this article are available with the author and will be produced on reasonable demand

\section{Ethics Approval}

Not applicable

\section{References}

Abaidoo RC, HH Keyser, PW Singleton, D Borthakur (2002). Comparison of molecular and antibiotic resistance profile methods for the population analysis of Bradyrhizobium spp. (TGx) isolates that nodulate the new TGx soybean cultivars in Africa. J Appl Microbiol 92:109-117

Abi-Ghanem R, JL Smith, GJ Vandemark (2013). Diversity of Rhizobium leguminosarum from pea fields in Washington state. Intl Scholar Res Notic Soil Sci 2013; Article 786030

Beck DP, LA Materon, F Afandi (1993). Pratical Rhizobium spp. Legume Technology Manula. In: International center for Agricultural Research in the Dry areas, pp:1-54. International center for agricultural research in dry areas (ICARDA), Aleppo, Syria,

Borucki W, M Sujkowska (2008). The effects of sodium chloride-salinity upon growth, nodulation and root nodule structure of pea (Pisum sativum L.) plants. Acta Physiol Plantarum 30:293-301

Bourion V, K Heulin-Gotty, V Aubert, P Tisseyre, M Chabert-Martinello, M Pervent, D Delaitre, D Vile, M Siol, G Duc, B Brunel, J Burstin, M Lopetit (2018). Co-inoculation of a pea core collection with diverse rhizobial strains shows competitiveness for nodulation and efficiency of nitrogen fixation are distinct traits in the interaction. Front Plant Sci 8; Article 2249

Ceccatto VM, JE Gomes, GA Sarries, DH Moon, SM Tsai (1998). Effects of host plant origin on nodulin activities and nitrogen fixation in Phaseolus vulgaris L. Plant Soil 204:79-87

Cordovilla MP, F Ligero, C Lluch (1994). The effect of salinity on N fixation and assimilation in Vicia faba. J Exp Bot 45:1483-1488
Dakora FD, CA Appleby, CA Atkins (1991). Effect of $\mathrm{PO}_{2}$ on the formation and status of leghemoglobin in nodules of cowpea and soybean Plant Physiol 95:723-730

Dawood MG, MS Adak, MMS Abdallah, B Bakry, OM Darwish (2019). Influence of biofertilizers on growth and some biochemical aspects of flax cultivars grown under sandy soil conditions. Bull Nat Res Ctr 43; Article 81

Erman M, B Yıldırım, N Togay, F Çiğ (2009). Effect of phosphorus application and Rhizobium inoculation on the yield, nodulation and nutrient uptake in field pea (Pisum sativum sp. arvense L.). J Anim Vet Adv 8:301-304

Fujita H, S Aoki, M Kawagucki (2014). Evolutionary Dynamics of nitrogen fixation in the legume rhizobia symbiosis. PLoS One 9; Article e93670

Gordon AJ (1991). Enzyme distribution between the cortex and the infected region of soybean nodules. J Exp Bot 42:961-967

Huang J, RK Afshar, A Tao, C Chen (2017). Efficacy of strater N fertilizer and rhizobia inoculant in dry pea (Pisum sativum Linn.) production in a semi-arid temperate environment. J Soil Sci Plant Nutr 63:248253

Jordan DC (1984). Family III, Rhizobiaceae Conn 1938. In: Bergey's Manual of Systematic Bacteriology, Vol. 1, pp:235-244. Krleg NR, JG Holt (Eds.). Williams and Wilkins Co., Baltimore, Maryland, USA

Kacar B, V Katkat (2007). Bitki Besleme. Nobel Yayınları

Küçük C C (2011). Inoculation with Rhizobium spp. in kidney bean (Phaseolus vulgaris L.) varieties. Žemdir Agric 98:49-56

Küçük C, M Kıvanç, E Kınacı (2006). Characterization of Rhizobium spp. isolated from bean. Turk J Biol 30:127-137

Meghvansi MK, K Prasad, SK Mahna (2010). Symbiotic potential, competitiveness and compatibility of indigenous Bradyrhizobium japonicum isolates to three soybean genotypes of two distinct agroclimatic regions of Rajasthan, India. Saudi J Biol Sci 17:303-310

Mishra PK, S Mishra, G Selvakumar, JK Bisht, S Kundu, HS Gupta (2009). Coinoculation of Bacillus thuningeinses-KR1 with Rhizobium leguminosarum enhances plant growth and nodulation of pea (Pisum sativum L.) and lentil (Lens culinaris L.). World J Microbiol Biotechnol 25:753-761

Muniz AW, MD Costa, ELSD Sa, AB Fiuza, E Brose (2017) Symbioticefficiency of pea (Pisum sativum) rhizobia association under field conditions. Afr J Agric Res 12:2582-2585

Mutch LA, PW Young (2004). Diversity and specificity of Rhizobium leguminosarum biovar vicia on wild and cultivated legumes. Mol Ecol 13:2435-2444

Peix A, MH Ramirez-Bahena, E Velazquez, EJ Bedmar (2015). Bacterial associations with legumes. Crit Rev Plant Sci 34:17-42

Riah N, G Bena, A Djekoun, K Heulin, P Lajudie, G Laguerre (2014). Genotypic and symbiotic diversity of Rhizobium populations associated with cultivated lentil and pea in sub-humid and semiarid regions of Eastern Algeria. Syst Appl Microbiol 37:368-375

Rodriguez AC, A Bonifacio, JEL Antunes, JAGd Silveira, MV Figueiredo (2014). Minimization of oxidative stress in cowpea nodules by the interrelationship between Bradyrhizobium spP. and plant growth promoting bacteria. Appl Soil Ecol 64:245-251

Singleton PW, SAE Swaify, BB Bohlol (1982). Effect of salinity on Rhizobium growth and survival. Appl Environ Microbiol 44:884-890

Wielbo J, A Podlesna, D Kidaj, J Podlesny, A Skorupska (2015). The diversity of pea microsymbionts in various types of soils and their effects on plant host productivity. Microb Environ 30:254-261 